\title{
Pengaruh Karakteristik Audit, Struktur Kepemilikan dan Return on Investment terhadap Prediksi Kebangkrutan Perusahaan Perdagangan
}

\author{
Sariyanto ${ }^{1}$, Nova Yesyca Naipospos ${ }^{2 *}$ \\ ${ }^{1)}$ Universitas Amir Hamzah, ${ }^{2}$ Politeknik LP3I Medan, Indonesia \\ keluarga3366@gmail.com, novayesyca@gmail.com
}

*Corresponding Author

Submitted: February 4, 2021

Accepted: February 23, 2021

Published: March 11, 2021

\begin{abstract}
This study aims to determine the effect of the characteristics of the audit committee, ownership structure and return on investment on the prediction of bankruptcy in trading companies listed. The research methodology used is descriptive quantitative method, and the data sources are secondary data. The population of this study is 49 trading companies listed on the Indonesia Stock Exchange for the 2017-2018 period and 16 companies which sample. The sample technique used in this study was purposive sampling. The data analysis technique of this research is multiple regression analysis using hypothesis testing, namely partial test ( $t$ test), simultaneous test ( $F$ test) and the coefficient of determination test. The results of the study partially show that the characteristics of the audit committee have no significant effect on the prediction of bankruptcy with a significance test of $-3.232<2.014$. Ownership structure has a significant effect on bankruptcy predictions with a value of 4.045> 2.014. Return on investment has no significant effect on bankruptcy predictions with a value of $1.325<2.014$. The results of the research simultaneously show that the characteristics of the audit committee, ownership structure and return on investment on the prediction of bankruptcy in trading companies listed on the Indonesia Stock Exchange have a significant effect with a value of 7.347> 2.81. Square obtained from the results of this study). The conclusion from the results of this study shows that partially the characteristics of the audit committee.
\end{abstract}

Keywords: Audit Committee; Bankruptcy Predictions; Ownership Structure; Return On Investment

\section{PENDAHULUAN}

Persaingan bisnis yang sangat ketat pada saat in dapat mengakibatkan gangguan terhadap kelangsungan hidup perusahaan, hal ini akan menimbulkan kerugian yang dapat menyebabkan kebangkrutan. Kebangkrutan perusahaan dapat terjadi dikarenakan perusahaan mengalami masalah keuangan yang dibiarkan berlarut-larut terutama kerugian timbul akibat tingkat penjualan yang rendah tetapi hutang perusahaan yang banyak. Salah satu alasan perusahaan menutup usahanya karena laba yang diperoleh perusahaan lebih kecil dari biaya yang dikeluarkan perusahaan selama jangka waktu tertentu. Perusahaan juga tidak dapat membayar kewajiban-kewajibannya kepada pihak lain pada saat jatuh tempo karena perusahaan tidak memperoleh laba setiap periode operasinya. Salah satu alat ukur tingkat kesulitan keuangan perusahaan adalah prediksi kebangkrutan. 
Perusahaan Enron, Xerox, dan WorldCom adalah contoh perusahaan berskala besar dunia yang memiliki kasus korporasi. Perusahaan-perusahaan ini terindikasi memiliki kegagalan bisnis akibat dari corporate governance yang buruk. Kegagalan bisnis dalam sebuah perusahaan, akan mendorong terjadinya prediksi kebangkrutan (KRISTANTI, 2019). Kasus lain yang menggambarkan kondisi prediksi kebangkrutan yang baru-baru ini terjadi adalah kasus Bank Century pada tahun 2008. Dalam kasus tersebut, Bank Century secara tiba-tiba dinyatakan pailit karena tidak dapat memenuhi kewajiban kliringnya terhadap Bank Indonesia (RIKKI JOSUA SILITONGA, 2017). Prediksi kebangkrutan merupakan tahap penurunan kondisi keuangan yang terjadi pada perusahaan.

Kondisi Keuangan Perusahaan yang terus menerus mengalami penurunan sebelum terjadinya kebangkrutan ataupun likuidasi adalah awal mulanya kondisi dimana kepercayaan masyarakat ataupun stake holder mulai berkurang bahkan mulai hilang. Apabila hal ini terus manerus terjadi dan tidak segera diselesaikan maka akan berdampak besar pada kebangkrutan perusahaan. Stakeholder yang berada di perusahaan memiliki struktur kepemilikan dalam organisasi perusahaan yang berkaitan dengan corporate governance. Ada empat mekanisme corporate governance yang sering dipakai dalam berbagai penelitian mengenai corporate governance yang bertujuan untuk mengurangi konflik keagenan, yaitu komposisi dewan, komite audit, kepemilikan institusional, dan kepemilikan manajerial. Komposisi dewan komisaris merupakan salah satu karakteristik dewan yang berhubungan dengan kandungan informasi laba. Melalui perannya dalam menjalankan fungsi pengawasan, komposisi dewan dapat mempengaruhi pihak manajemen dalam menyusun laporan keuangan sehingga dapat diperoleh suatu laporan laba yang berkualitas(Widyaningsih, 2017).

\section{Rumusan Masalah}

Berdasarkan uraian dari latar belakang di atas, dirumuskan masalah penelitian adalah: Apakah karakteristik komite audit, kepemilikan dan return on investment berpengaruh terhadap prediksi kebangkrutan pada perusahaan perdagangan yang terdaftar di Bursa Efek Indonesia?

\section{Kerangka Pemikiran Teoritis}

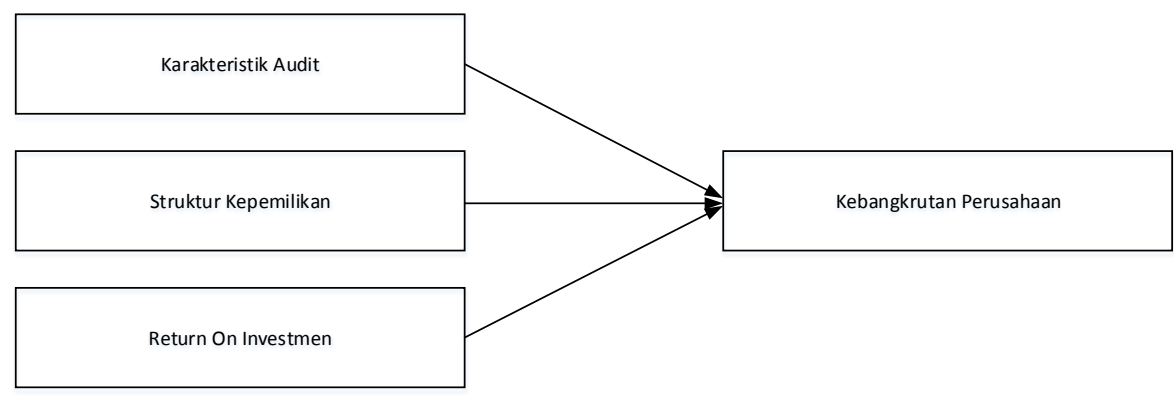

Sumber : Peneliti 2020

Gambar 1.1 Kerangka Pemikiran Teoritis

\section{STUDI LITERATUR}

Persaingan bisnis pada saat ini yang tajam dan dapat mengakibatkan kelangsungan hidup perusahaan terganggu sehingga menimbulkan kerugian yang akhirnya menyebabkan kebangkrutan bagi perusahaan. Kebangkrutan perusahaan dapat terjadi dikarenakan perusahaan mengalami masalah keuangan yang dibiarkan berlarut-larut terutama kerugian timbul akibat tingkat penjualan yang rendah tetapi hutang perusahaan yang banyak (Dewi Teresia \& Hermi, 2016). Salah satu alasan perusahaan menutup usahanya karena laba yang diperoleh perusahaan lebih kecil dari biaya yang dikeluarkan perusahaan selama jangka waktu tertentu. Perusahaan juga tidak dapat membayar kewajiban-kewajibannya kepada pihak lain pada saat jatuh tempo karena perusahaan tidak 
memperoleh laba setiap periode operasinya. Salah satu alat ukur tingkat kesulitan keuangan perusahaan adalah prediksi kebangkrutan(Sanny \& Warastuti, 2020)

Menurut (Sujarweni, 2017), pengertian kebangkrutan sendiri bisa dilihat dari pendekatan aliran kas dan pendekatan stok. Dengan menggunakan pendekatan stok, perusahaan bisa dinyatakan bangkrut jika total kewajiban melebihi total aktiva. Jika perusahaan mempunyai utang Rp 1 milyar, sedangkan total asetnya hanya Rp. 500.000.000, maka perusahaan tersebut sudah bisa dinyatakan bangkrut. Dengan menggunakan pendekatan aliran, perusahaan akan bangkrut jika tidak bisa menghasilkan aliran kas yang cukup (Effendi, 2018). Dari sudut pandang stok, perusahaan bisa dinyatakan bangkrut meskipun mungkin masih menghasilkan aliran kas yang cukup, atau mempunyai prospek yang baik di masa mendatang (NY Naipospos; Khairunnida, 2020).

Salah satu faktor yang mempengaruhi tingkat kebangkrutan adalah return on investment dimana pengukuran tingkat laba berdasarkan seluruh aktiva yang dimiliki perusahaan (Lubis, 2019). Dengan adanya kecukupan dana tersebut maka kemungkinan perusahaan mengalami kebangkrutandi masa yang akan datang akan menjadi lebih kecil. Apabila perusahaan memiliki return on investment yang rendah tentu dapat mengakibatkan perusahaan berada dalam keadaan bangkrut. Namun pada tahun 2015 ini, kebanyakan perusahaan berada dalam keadaan bangkrut dikarenakan laba perusahaan yang rendah. Jika perusahaan yang tidak berada dalam keadaan bangkrut dengan perusahaan memiliki laba yang tinggi sehingga mampu menutupi kesulitan keuangan perusahaan (Sunaryo \& Mahfud, 2016).

Menurut (Mutiara, 2018), dewan komisaris harus menetapkan suatu komite audit yang terdiri atas anggota komisaris yang dipilih, auditor luar dan anggota puncak dari staf audit internal. Ukuran komite audit merupakan jumlah anggota komite dalam perusahaan. Skala nominal menurut (Ghozali, 2018) merupakan skala pengukuran yang mengatakan kategori atau kelompok dari suatu subyek. Skala yang digunakan dalam pengukuran jumlah anggota komite audit ini dalam laporan tahunan perusahaan terdapat pada tata kelola perusahaan (Sunaryo \& Mahfud, 2016) Menurut (Indriyani, 2017), semua perusahaan publik yang menaruh sahamnya di bursa saham diwajibkan memiliki komite audit yang terdiri dari direktur-direktur luar. Efektivitas komite audit akan meningkat jika ukuran komite meningkat, karena komite memiliki sumber daya yang lebih untuk menangani masalah-masalah yang dihadapi oleh perusahaan. Oleh karena itu, diharapkan keberadaan komite audit yang efektif dapat mengubah kebijakan yang berbeda dalam pencapaian laba akuntansi pada beberapa tahun ke depan sehingga perusahaan dapat menghindari terjadinya permasalahan keuangan karena kurangnya kinerja yang baik. Kinerja tersebut dapat diwujudkan dengan adanya tim yang terdiri dari beberapa orang yang berpengalaman.

Menurut (Mutiara, 2018), suatu tolok ukur yang penting dari mutu internal auditing adalah tingkat dalam organisasi auditor intern melapor. Sebaiknya auditor intern harus melaporkan kepada tingkat manajemen yang cukup tinggi agar temuan audit dapat diterapkan.

Menurut (Kasmir, 2017), rasio profitabilitas merupakan rasio untuk menilai kemampuan perusahaan dalam mencari keuntungan. Menurut Sunyoto (Indriyani, 2017), pengertian dari profitabilitas adalah kemampuan perusahaan untuk memperoleh keuntungan dari usahanya. Menurut (Fahmi, 2017), ROI adalah rasio ini melihat sejauh mana investasi yang telah ditanamkan mampu memberikan pengembalian keuntungan sesuai dengan yang diharapkan. Dan investasi tersebut sebenarnya sama dengan aset perusahaan yang ditanamkan atau ditempatkan.

\section{Metode Analisis Data Penelitian}

\section{METODE}

Dalam penelitian ini, metode analisis data yang digunakan adalah metode analisis statistik dengan menggunakan software SPSS 19.0. Data yang terkumpul dalam penelitian ini akan dianalisis secara kuantitatif dengan menggunakan metode sebagai berikut :

\section{Statistik deskriptif}

Menurut (Wijaya, 2018), statistik deskriptif adalah statistik yang digunakan untuk menganalisa data dengan cara mendeskripsikan atau menggambarkan data yang telah terkumpul 
sebagaimanna adanya tanpa bermaksud membuat kesimpulan yang berlaku untuk umum atau generalisasi. Statistik deskripsi memberikan gambaran atau deskripsi suatu data yang dilihat dari nilai rata-rata (mean), standar deviasi, maksimum, dan nilai minimum.

\section{Analisis Regresi Linear Berganda}

Menurut Narimawati (2018:5), analisis regresi linear berganda yaitu suatu analisis asosiasi yang digunakan secara bersamaan untuk meneliti pengaruh dua atau lebih variabel bebas terhadap satu variabel tergantung dengan skala interval.Adapun persamaan regresi yang digunakan adalah sebagai berikut:

$$
\mathrm{Y}=\alpha+\mathrm{b}_{1} \mathrm{X}_{1}+\mathrm{b}_{2} \mathrm{X}_{2}+\mathrm{b}_{3} \mathrm{X}_{3}+\mathrm{e}
$$

\section{HASIL}

Penelitian ini menggunakan laporan keuangan perusahaan perdagangan yang terdaftar di Bursa Efek Indonesia pada periode 2017-2018 yang menjadi sampel yang telah diinput dapat dilihat nilai maksimum, minimum, mean dan standar deviasi dari masing-masing variabel penelitian pada tabel 4.1 sebagai berikut.

Tabel 4.1. variabel Penelitian

\begin{tabular}{|l|l|l|l|l|l|}
\hline \multicolumn{6}{|l|}{ Descriptive Statistics } \\
\hline
\end{tabular}

Sumber : Peneliti

\section{Hasil Uji Asumsi Klasik}

Peneliti melakukan penelitian dengan data yang telah dihitung rasionya maka peneliti menggunakan uji asumsi klasik dapat disajikan di bawah ini seperti uji normalitas, uji heteroskedastisitas, uji autokorelasi, dan uji multikolinieritas.

\section{Uji Normalitas}

Penelitian ini dapat dilihat dengan menggunakan analisis histogram dan normal probability plot. Berikut tampilan kedua grafik tersebut:

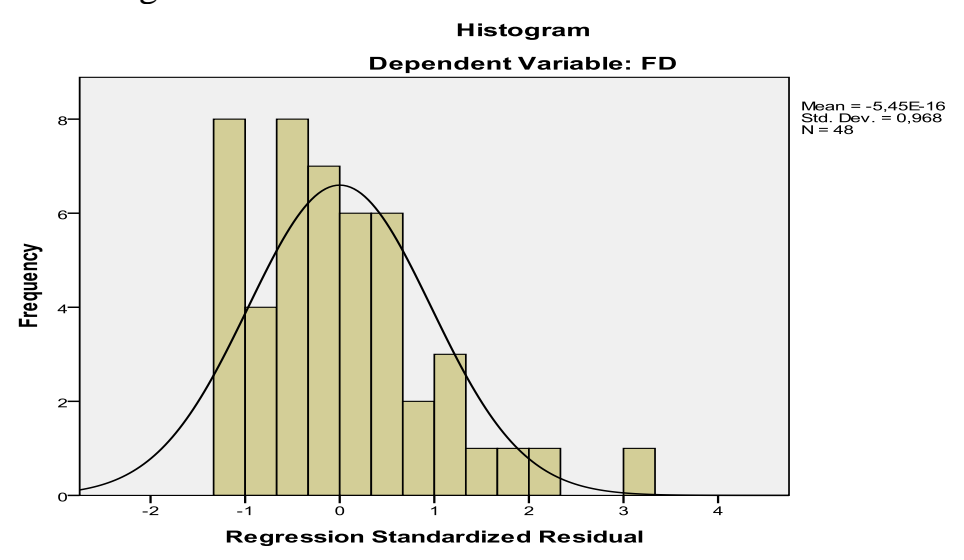

Gambar 4.1. Histogram

Sumber : Data sekunder

Dari gambar 4.1 histogram di atas, dapat disimpulkan data residual berdistribusi normal karena bisa dilihat dari arah histogram yang tidak miring ke kiri dan membentuk lonceng terbalik 
Owner: Riset \& Jurnal Akuntansi

e-ISSN : 2548-9224 |p-ISSN : 2548-7507

Volume 5 Nomor 1, Februari 2021

DOI : https://doi.org/10.33395/owner.v5i1.386

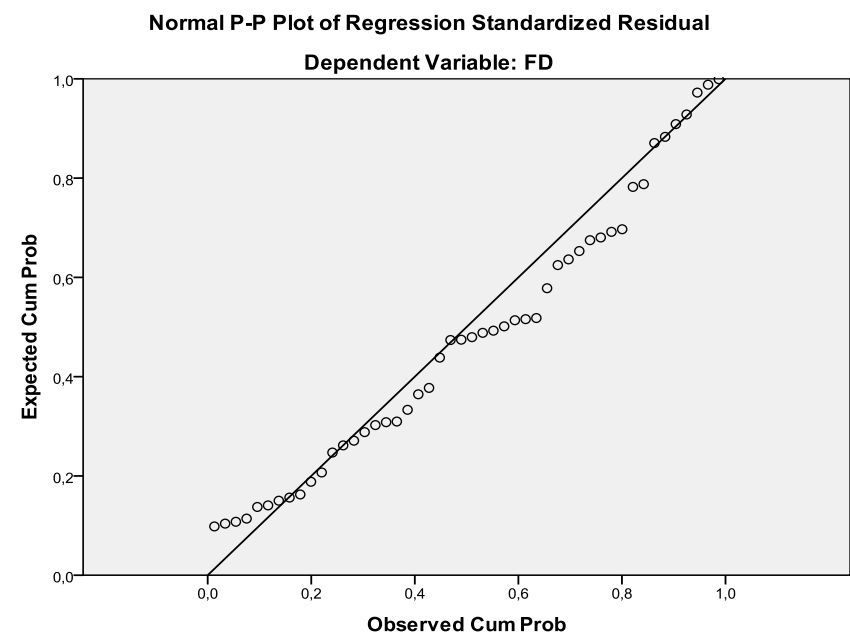

Gambar 4.2. Normal Probability Plot

Sumber : Data Statistik

Dari Gambar 4.2 dapat disimpulkan terlihat titik-titik menyebar mengikuti arah garis diagonal maka dapat disimpulkan bahwa karakteristik komite audit, struktur kepemilikan, return on investment dan prediksi kebangkrutan memiliki data berdistribusi secara normal. Penelitian ini juga menggunakan uji asumsi normalitas yaitu uji statistik non parametrik Kolmogorov Smirnov Test dengan pedoman pengambilan keputusan rentang data mendekati atau merupakan distribusi normal

Tabel 4.2. Uji asumsi Normalitas

\begin{tabular}{|l|l|r|}
\hline \multicolumn{2}{|c|}{ One-Sample Kolmogorov-Smirnov Test } \\
\hline \multirow{2}{|c|}{} & Unstandardized Residual \\
\hline \multirow{2}{*}{ Normal Parameters ${ }^{a, b}$} & Mean & 48 \\
\cline { 2 - 3 } & Std. Deviation &, 0000000 \\
\hline \multirow{2}{*}{ Most Extreme Differences } & Absolute &, 92562678 \\
\cline { 2 - 3 } & Positive &, 127 \\
\cline { 2 - 3 } & Negative &, 127 \\
\hline Kolmogorov-Smirnov Z &,- 091 \\
\hline Asymp. Sig. (2-tailed) &, 881 \\
\hline a. Test distribution is Normal. &, 420 \\
\hline b. Calculated from data. \\
\hline
\end{tabular}

Sumber : Data penelitian

\section{Hasil Analisis Regresi Linier Berganda}

Tabel 4.5. Regresi Linier Berganda

\begin{tabular}{|c|c|c|c|c|c|c|}
\hline \multicolumn{7}{|c|}{ Coefficients $^{a}$} \\
\hline \multirow[b]{2}{*}{ Model } & \multicolumn{3}{|c|}{ Unstandardized Coefficients } & \multirow{2}{*}{$\begin{array}{l}\text { Standardized Coefficients } \\
\text { Beta }\end{array}$} & \multirow[b]{2}{*}{$t$} & \multirow[b]{2}{*}{ Sig. } \\
\hline & $B$ & & Error & & & \\
\hline 1 & (Constant) & 6,190 & ,951 & & 6,511 & 000 \\
\hline & Komite Audit & $-1,099$ & 340 &,- 488 & $-3,232$ & 002 \\
\hline & K.Institusional & 1,031 &, 255 & 625 & 4,045 &, 000 \\
\hline & ROI &, 070 &, 053 &, 171 & 1,325 & ,192 \\
\hline
\end{tabular}

a. Dependent Variable: Prediksi Kebangkrutan

Sumber : Data Statistik 
Tabel 4.6. Koefisien Determinasi

Sumber : Data statistik

\begin{tabular}{|l|l|l|l|l|}
\hline \multicolumn{6}{|l|}{ Model Summary } \\
\hline Model & $R$ & $R$ Square & Adjusted $R$ Square & Std. Error of the Estimate \\
\hline 1 &, $578^{\text {a }}$ &, 334 &, 288 &, 95666 \\
\hline a. Predictors: (Constant), ROI, KM, KI \\
\hline
\end{tabular}

\section{PEMBAHASAN}

Karakteristik Komite Audit Terhadap Prediksi Kebangkrutan

Hasil penelitian ini menunjukkan bahwa karakteristik komite audit berpengaruh tidak signifikan terhadap prediksi kebangkrutan. Hal ini di buktikan dengan hasil uji signifikansi pada tabel 4.7 Tabel hasil Uji F berikut:

Tabel 4.7 Hasil Uji F

Anova $^{b}$

\begin{tabular}{|c|c|c|c|c|c|c|}
\hline \multirow[b]{2}{*}{ Model } & & Mean & \multirow[b]{2}{*}{$F$} & \multirow[b]{2}{*}{ Sig. } \\
\hline & Sun of Squares & \multicolumn{2}{|c|}{$d f$} & Square & & \\
\hline 1 & Regression & 2,0171 & 3 & 6,724 & 7,347 &, 000 \\
\hline & Residual & 4,0269 & 44 & ,915 & & \\
\hline & Total & 6,0440 & 47 & & & \\
\hline
\end{tabular}

Sumber : Data statistik

Dari tabel 4.7 ini, menggambarkan bahwa variabel karakteristik komite audit mempunyai nilai $t_{\text {hitung }}$ adalah sebesar $-3,232$ dan nilai $t_{\text {tabel }}$ adalah sebesar 2,014 dengan nilai signifikan 0,002 lebih kecil signifikan 0,05. Dikarenakan -3,232<2,014, yang berarti karakteristik komite audit berpengaruh tidak signifikan terhadap prediksi kebangkrutan. Berdasarkan hipotesis tersebut kesulitan keuangan secara signifikan berhubungan dengan keahlian anggota komite audit di bidang keuangan, komite audit perusahaan yang kurang pengetahuan di bidang akuntansi dan keuangan.

Hasil penelitian ini sesuai dengan replikasi penelitian (Indrasari et al., 2017) yang menyatakan, independensi komite audit tidak berpengaruh signifikan terhadap financial distress.

\section{Pengaruh Struktur KepemilikanTerhadap Prediksi Kebangkrutan}

Hasil penelitian ini menunjukkan bahwa struktur kepemilikan berpengaruh signifikan terhadap prediksi kebangkrutan dengan nilai $t_{\text {hitung }} 4,045$ dan nilai $t_{\text {tabel }}$ adalah sebesar 2,014 dengan nilai signifikan 0,000 lebih kecil signifikan 0,05. Dikarenakan 4,045>2,014, maka hasil pengujian menunjukkan $\mathrm{H} 2$ diterima.

Hasil penelitian ini tidak sesuai dengan replikasi penelitian Manurung dan Wibisono (2015), yang menyatakan struktur kepemilikan memiliki pengaruh signifikan terhadap kemungkinan perusahaan mengalami kondisi financial distress.

\section{Pengaruh Return on Investment Terhadap Prediksi Kebangkrutan}

Hasil penelitian ini menunjukkan bahwa return on investment tidak berpengaruh tidak signifikan terhadap prediksi kebangkrutan dikarenakan perusahaan yang mengalami financial distress yang besar maupun tidak dipengaruhi oleh tingkat laba bersih yang diperolehnya, dengan variabel return on investment mempunyai nilai $t_{\text {hitung }} 1,325$ dan nilai $t_{\text {tabel }}$ adalah sebesar 2,014 dengan nilai signifikan 0,192 lebih besar signifikan 0,05. Dikarenakan 1,325<2,014, maka hasil pengujian menunjukkan $\mathrm{H} 3$ ditolak.

Pengaruh Karakteristik Komite Audit, Struktur Kepemilikan dan Return On Investment TerhadapPrediksi Kebangkrutan 
Hasil penelitian ini menunjukkan bahwa karakteristik komite audit, kepemilikan institusional, dan return on investment berpengaruh signifikan terhadap prediksi kebangkrutan dengan variabel hasil $F_{\text {hitung }}$ adalah sebesar 7,347 dan nilai $F_{\text {tabel }}$ adalah sebesar 2,81 dengan nilai signifikan 0,000<0,05.Dikarenakan 7,347> 2,81, maka hasil pengujian menunjukkan $\mathrm{H} 4$ diterima. Hasil penelitian ini tidak sesuai dengan replikasi penelitian Nuresa yang menyatakan, komite audit dan pengetahuan keuangan komite audit berpengaruh negatif secara signifikan terhadap kesulitan keuangan. Namun pada penelitian lain, Hasil penelitian ini tidak sesuai dengan replikasi penelitian Manurung dan Wibisono (2015) yang menyatakan, struktur kepemilikan memiliki pengaruh signifikan terhadap kemungkinan perusahaan mengalami kondisi financial distress. Hasil penelitian ini tidak sesuai dengan replikasi penelitian Sutrisno dan Liana yang menyatakan, profitabilitas (NPM) berpengaruh signifikan dan positif terhadap financial distress.

\section{KESIMPULAN}

Secara parsial, karakteristik komite audit tidak berpengaruh signifikan terhadap prediksi kebangkrutan dengan hasil uji signifikansi diatas,variabel karakteristik komiteaudit mempunyai nilai $t_{\text {hitung }}$ adalah sebesar $-3,232$ dan nilai $t_{\text {tabel }}$ adalah sebesar 2,014 dengan nilai signifikan 0,002 lebih kecil signifikan 0,05.Dikarenakan-3,232<2,014, maka hasil pengujian menunjukkan H1 di tolak.Secara parsial, struktur kepemilikan berpengaruh signifikan terhadap prediksi kebangkrutan dengan nilai $t_{\text {hitung }} 4,045$ dan nilai $t_{\text {tabel }}$ adalah sebesar 2,014 dengan nilai signifikan 0,000lebih kecil signifikan 0,05. Dikarenakan 4,045>2,014,maka hasil pengujian menunjukkan H2diterima. Secara parsial, return on investment tidak berpengaruh tidak signifikan terhadap prediksi kebangkrutandikarenakan perusahaan yang mengalami financial distress yang besar maupun tidak dipengaruhi oleh tingkat laba bersih yang diperolehnya, dengan variabel return on investment mempunyai nilai $t_{\text {hitung }} 1,325$ dan nilai $t_{\text {tabel }}$ adalah sebesar 2,014 dengan nilai signifikan 0,192 lebih besar signifikan 0,05. Dikarenakan 1,325<2,014, maka hasil pengujian menunjukkan H3 ditolak. Secara simultan, karakteristik komite audit, struktur kepemilikan dan return on investment terhadap prediksi kebangkrutan pada perusahaan perdagangan yang terdaftar di Bursa Efek Indonesia berpengaruh signifikan dengannilaiF $F_{\text {hitung }}$ adalah sebesar 7,347 dan $\mathrm{F}_{\text {tabel }}$ adalah sebesar 2,81 dengan nilai signifikan 0,000 > 0,05. Dikarenakan 7,347 > 2,81, maka hasil pengujian menunjukkan $\mathrm{H} 4$ diterima. Besarnya pengaruh yang diberikan oleh variabel karakteristik komite audit, struktur kepemilikan dan return on investment terhadap prediksi kebangkrutan pada perusahaan perdagangan yang terdaftar di Bursa Efek Indonesiaadalah sebesar 22,8\% (sesuai dengan nilaiAdjusted $R^{2}$ yang diperoleh dari hasil penelitian ini).

\section{REFERENSI}

Dewi Teresia, E. S., \& Hermi, H. (2016). PENGARUH STRUKTUR KEPEMILIKAN, UKURAN PERUSAHAAN DAN KEPUTUSAN KEUANGAN TERHADAP NILAI PERUSAHAAN DENGAN PERTUMBUHAN PERUSAHAAN SEBAGAI VARIABEL MODERATING. Jurnal Magister Akuntansi Trisakti. https://doi.org/10.25105/jmat.v3i1.4969

Effendi, R. (2018). Analisis Prediksi Kebangkrutan Dengan Metode Altman, Springate, Zmijewski, Foster, Dan Grover Pada Emiten Jasa Transportasi. Jurnal Parsimonia.

Fahmi, I. (2017). Analisis Kinerja Keuangan Panduan bagi Akademisi, Manajer, dan Investor untuk Menilai dan Menganalisis Bisnis dari ASpek Keuangan. In CV ALFABETA.

Ghozali, I. (2018). Aplikasi Analisis Multivariate Dengan Program IBM SPSS 25 Edisi 9. In International Journal of Physiology.

Indrasari, A., Yuliandhari, W. S., \& Triyanto, D. N. (2017). PENGARUH KOMISARIS INDEPENDEN, KOMITE AUDIT, DAN FINANCIAL DISTRESS TERHADAP

INTEGRITAS LAPORAN KEUANGAN. Jurnal Akuntansi.
https://doi.org/10.24912/ja.v20i1.79

Indriyani, E. (2017). Pengaruh Ukuran Perusahaan dan Profitabilitas Terhadap Nilai Perusahaan. Akuntabilitas. https://doi.org/10.15408/akt.v10i2.4649

Kasmir. (2017). Pengaruh risiko kredit, risiko likuiditas, dan permodalan terhadap profitabilitas 
perbankan (Studi Kasus pada Bank Umum Go Public yang Terdaftar di Bursa Efek Indonesia Tahun 2012-2015). FAKULTAS EKONOMI DAN BISNIS.

KRISTANTI, S. (2019). ANALISIS FINANCIAL DISTRESS DAN PENGARUHNYA TERHADAP RETURN SAHAM PERUSAHAAN MANUFAKTUR YANG TERDAFTAR DI BURSA EFEK INDONESIA. Equator Journal of Management and Entrepreneurship $(E J M E)$. https://doi.org/10.26418/ejme.v7i4.34573

Lubis, I. T. (2019). Pengaruh Karakteristik Komite Audit, Struktur Kepemilikan Dan Return On Investment Terhadap Prediksi Kebangkrutan Pada Perusahaan Perdagangan Yang Terdaftar Di Bursa Efek Indonesia. Ready Star.

Mutiara, I. (2018). PENGARUH KOMPETENSI DAN INDEPENDENSI AUDITOR TERHADAP KUALITAS AUDIT DENGAN ETIKA AUDITOR SEBAGAI VARIABEL MODERASI. JURNAL RISET AKUNTANSI JAMBI. https://doi.org/10.35141/jraj.v1i2.60

NY Naipospos; Khairunnida; (2020). Pengendalian Internal terhadap Penerimaan Negara Bukan Pajak (PNBP) melalui Penerapan Peraturan Pemerintah Republik Indonesia Nomor 46 Tahun 2002 pada Kantor Wilayah. Juripol, 2(2), 67.

RIKKI JOSUA SILITONGA. (2017). KEDUDUKAN BANK INDONESIA SEBAGAI PEMOHON PAILIT BANK SETELAH BERDIRINYA OTORITAS JASA KEUANGAN. 11.

Sanny, S., \& Warastuti, Y. (2020). Analisis Pengaruh Kinerja Keuangan dan Tata Kelola Perusahaan Terhadap Kondisi Kesehatan Keuangan Perusahaan. Jurnal Akuntansi Bisnis. https://doi.org/10.24167/jab.v18i1.2702

Sujarweni, V. W. (2017). Analisis Laporan Keuangan teori, aplikasi, dan hasil penelitian. In Analisis Laporan Keuangan teori, aplikasi, dan hasil penelitian.

Sunaryo, B. A., \& Mahfud, H. M. K. (2016). Pengaruh Size, Profitabilitas, Leverage Dan Umur Terhadap Pengungkapan Tanggung Jawab Sosial Perusahaan (Studi Empiris Perusahaan Manufaktur Yang Listing Di BEI TAHUN 2010 - 2013). Diponegoro Journal of Management.

Widyaningsih, H. (2017). PENGARUH CORPORATE GOVERNANCE TERHADAP MANAJEMEN LABA. Nominal, Barometer Riset Akuntansi Dan Manajemen. https://doi.org/10.21831/nominal.v6i2.16652

Wijaya, H. (2018). Analisis Data Kualitatif Model Spradley (Etnografi). Sekolah Tinggi Theologia Jaffray. 